\title{
The Effects of Vocational High School Teachers' Perceived Trust on Organizational Silence
}

\author{
Aycan Çiçek Sağlam \\ Correspondence: Aycan Çiçek Sağlam, Educational Administration, Muğla Sitkı Koçman University, Turkey.
}

Received: March 21, 2016 Accepted: April 15, $2016 \quad$ Online Published: April 15, 2016

doi:10.11114/jets.v4i5.1474

URL: http://dx.doi.org/10.11114/jets.v4i5.1474

\begin{abstract}
The objective of this research is to reveal the effects of vocational school teachers' perceived organizational trust on organizational silence. For this purpose, at first teachers' perception on sub-dimensions of organizational silence and organizational trust, which are respectively "acquiescent silence", "defensive silence", "prosocial silence" and "sensibility to employees", "trust to administrator", "openness to modernity", "communication climate", is tried to be identified. Then, the relationship among the sub-dimensions of organizational silence and organizational trust is determined. The research is conducted in correlational survey model. The research population consists of 293 teachers working in five vocational and technical high schools located in central Uşak province. Since the study is limited to vocational and technical high school teachers and sample size is not so large, no sampling is done and the scale is applied to all teachers. $160(54.6 \%)$ out of $183(62.4 \%)$ returned scales are evaluated after eliminating 23 incorrectly filled scales. During the study two different scales is used to gather data. One of them is "Organizational Trust Scale", developed by Daboval, et al. (1994), adopted to Turkish by Kamer (2001) and adopted to educational institutions by Yilmaz (2005) and, the other one is "Organizational Silence Scale", developed by Dyne, Ang \& Botero (2003) and adopted to Turkish by Erdoğan (2011). The findings are revealed that vocational high school teachers' perception about organizational trust is at high level, while their organizational silence behavior is at medium level. Moreover, a significant and two-way relationship between organizational trust and organizational silence is found.
\end{abstract}

Keywords: organizational trust, organizational silence, teachers' organizational trust, teachers' organizational silence

\section{Introduction}

In order to continue its existence, every organizations, regardless of its organizational type, rely on effective human resources. Therefore, employees trust in the administration of their organizations would let them work more effectively and efficiently. The employees who feel secure would contribute to the organization more, since they would have increased motivation and creativity. This is more important for educational institutions, since they drive the future of the societies. A strong and healthy society is only possible with individuals who perform their duties properly and contribute to their organizations at their best. The employees having trust in the organization would tend to use any kind of information for the benefit of the organization and increase the possibility of reaching the organizational goals. On the other hand, the employees who do not have trust in their organizations would tend to maintain their silence and utilize less of their potential. Therefore, organizational trust and organizational silence are interrelated. In developing countries, like Turkey, vocational and technical high school teachers with higher organizational trust and lower organizational silence is of greater importance, as they raise the high-quality intermediate staff needed in this rapid period of growth in technology and industry.

The phenomenon of trust is rooted in the contemporary administration approaches. The organizations with higher trust level provide more authority and responsibility to lower levels bring out a flexible working environment, based on team work (Y1lmaz, 2009). The trust to workplace has various positive effects on organizational administration and interpersonal relationships. The organizational trust also decreases costs, increases collaboration between the staff and developes the organization (Ning, Jin \& Mingxuan, 2007). According to Mishra \& Morrissey (1990 as cited in Çokluk Bökeoğlu \& Yılmaz, 2008), organizational trust is an employee's perception about support given to him/her, and being trustworthy of the leader and keeping his/her promise. This definition also means that trust forms the foundation of all relationships in the organization, both on horizontal and vertical levels. According to Memduhoğlu \& Zengin (2011), openness to changes and innovations shows higher trust level for an organization. 
Literature review shows that organizational trust has been studied in two separate parts as "trust to the organization" and "trust to the administrator". Trust to the organization is defined as an individual's confidence that the organization would act in favour of him/her, or at least not act in a way to harm him/her. This type of trust focuses on the organization, rather than the individual. Trust to the administrator, on the other hand, is the trust of employees to the administrator. When the employees trust to an administrator, this trust gets reflected to the entire organization, because they see the administrator as the representative of the organization. Therefore, this type of trust must be built by the administrator (Karaca Cakınberk, Polat Dede \& Yılmaz, 2014)

For schools, effective communication among administrators, teachers, students, other staff and parents brings out higher levels of trust. The trust at schools is not only limited to interpersonal relationships. Basic administrative practices such as opinion taking, joint decision making, performance evaluation, and fairness in rewarding also affects organizational trust. Therefore, the administrator has the decisive role in establishing trust atmosphere at schools. The employees at schools trust to their administrators if they believe in their sincerity. This sincerity can be observed in the words and behaviors of an administrator (Memduhoğlu \& Zengin, 2011).

In societies with rapid pace of information and technology, administration approaches has also diversified. Instead of unconditioned obedience to seniors' orders, it is important to have environments where employees are part of the process and express their opinions on administration and operation freely. For this reason, having high self-esteem, valuing teamwork and having critical point of views to the organization employees have become desired. However, so many organizations seem to have lack of understanding in these new circumstances that they do not adopt it. As a result employees keeps their silence in order to maintain themselves or their positions. Because emloyees tend to accept majority's opinion as a criteria in order to be part of the organization, and this is where organizational silence becomes apparent as an important concept (Çakıcı, 2010).

Scott (1993) defines silence as keeping and not telling opinions and thoughts deliberately, while Nakane (2006) defines it as a behavior of avoidance from potential troubles, issues or problems. According to Bowen \& Blackmon, (2003) employees tend to express their opinions only if they match with the general opinion structure of the organization's, and prefer to keep them to themselves otherwise. According to Çakıcı (2007), if people think that they are alone in what they feel, they instinctivelydo not tell and hide it. Since if they are in minority in what they feel, they think that their opinions and thoughts are not be valued.

Organizational silence is defined as withholding of opinions, thoughts and concerns about the organizational problems (Morrison \& Milliken, 2000). This withholding is seen to be an intentional and deliberate silence of the employee. Many organizations face organizational silence. When faced with such a situation, it is necessary to clarify why and how the employees have become silent, the subjects they are reluctant to talk about, who they share issues and problems related to the organization with, how they decide the people to talk to or keep silent to, and how silence should be understood (Milliken, Morrison \& Hewlin, 2003). Organizational silence could be expressed in various terms. Pinder \& Harlos (2001) have divided silence into two as acquiescent silence and quiescent silence. Dyne, Ang \& Botero (2003) have categorized silence into three as acquiescent silence, defensive silence and prosocial silence. An employee in acquiescent silence fully acknowledges the status quo in the organization and neglects the circumstances that could change the status quo, since it is risky to change, therefore he/she feels secure by accepting them. Defensive silence is defined as conscious silence of the individual to protect him/herself against possible consequences. Prosocial silence is defined as an employees' keeping his silence on his opinions, thoughts, knowledge and point of views for the benefit of the organization, other individuals or for cooperative reasons.

It is quite important for the organization to consist of employees having high level of organizational commitment, organizational trust, motivation and job satisfaction. This can be reached by a democratic, participative, flexible, decentralized, natural, and communicative organizational structure. Besides, factors decreasing the efficiency, motivation and performance of the employees are considered to be threats to the organization. One of these threats is organizational silence and it is an important issue to be deal with (Yüksel, 2014). Bowen \& Blackmon (2003) state that silence having a major effect on organization shows up when the employees provide no contribution to their organizations. They stress although the behavior of silence is everywhere and quite important for the organization it is not studied. It is stated that the employees keep their silence to protect themselves and their families, as a result organizational silence emerge.

It is quite important for a school as an educational institution to reach stated visions. To reach intended aims it is necessary for a school staff to work in collaboration and harmony. When looked at the research findings related to the subject it is seen that (Bayram, 2010; Kahveci, 2010; Kolay, 2012; Yanık, 2012) teachers cannot express their problems, emotions and opinions freely, therefore they prefer to stay silent about the problems at school, and maintain their silence when they face criticism from their administrators and collegues. Although organizational silence and trust is important 
for all educational institutions, its importance is even greater for vocational and technical high schools where this study has been conducted. Different than other high school kinds these schools raise intermediate staff directly for the industry. In other words, the youth graduated from these scholls are more likely to be recruited as workforce in blue collar. Therefore, they need to pass through a more rigorous theoretical and practical education about their future professions. For these reasons, it is important to keep their teachers motivated. And, teachers trust to the administration and their silence behavior are needed to be taken into consideration for the productivity of the teachers.

As one of the developing countries, in Turkey the research studies conducted on organizational trust in educational institutions (Çağlar, 2011; Çokluk Bökeoğlu \&Yılmaz, 2008; Özer, Demirtaş, Üstüner \& Cömert, 2006; Memduhoğlu \& Zengin, 2011; Y1lmaz, 2009; Y1ld1z, 2013) have revealed that organizational trust is either at low or medium level. The only study directly related to organizational trust and organizational silence has been conducted at higher education level (Karaca Cakınberk et al., 2014). Similarly, research studies on organizational silence have revealed that (Alparslan, 2010; Bayram, 2010; Çakıc1, 2008; Kahveci, 2010; Kolay, 2012, Yüksel, 2014) organizational silence exists. Considering the importance of educational institutions for the development of the country, this subject is needed to be taken seriously. The silence would limit employees' contribution to the organizations, and decrease the productivity within the organization. The trust to the organization is the key issue in silence. So, it is important to reveal the perceived effects of organizational trust on organizational silence. Since Turkey is a country with centralized administration, duty assignments heavily rely on internal politics. As a result it takes time to teachers to build trust to their administrators and defensive silence behavior is seen to be protected. Therefore it is important to reveal the effect of organizational trust on employees' organizational silence and take measures to improve this issue. Moreover, since there are a few studies on the relationship between organizational silence and organizational trust, this study hopefully attracts researchers' attention to the subject and contribute to the literature.

\section{Objective of the Study}

The objective of this study is to reveal the effects of perceived organizational trust of vocational high school teachers on organizational silence. For this purpose, following sub-questions are tried to be answered:

1. What is the teachers' perception about sub-dimensions of organizational silence "acquiescent silence", "defensive silence", "prosocial silence" and organizational silence in general?

2. What is the teachers' perception about sub-dimensions of organizational trust "sensibility to employees", "trust to administrator", "openness to modernity", "communication climate" and organizational trust in general?

3. Is there a significant relationship between teachers' silence and perceived trust to the school administration?

4. Does teachers' perceived trust to school administration significantly predict organizational silence?

\section{Methodology}

\subsection{Research Model}

This research has been conducted in correlational survey model. The correlational survey models reveal the existence or level of concurrent changes between two or more variables (Karasar, 2006).

\subsection{Study Group}

The study group consists of 293 teachers working at five vocational and technical high schools at Uşak provincial center. Since the study is limited to vocational and technical high school teachers teachers and sample size is not so large, no sampling is done and the scale is applied to all teachers. $160(54.6 \%)$ out of $183(62.4 \%)$ returned scales have been evaluated after eliminating 23 incorrectly filled scales. 87 of 160 teachers are male, while 73 of them are female.

\subsection{Data Gathering Tools}

Two different scales are used to gather data, first one is "Organizational Trust Scale", developed by Daboval, Comish, Swindle \& Gaster (1994), adapted to Turkish by Kamer (2001) and re-adapted for schools and its reliability and validity has been tested for educational institutions by Yilmaz (2005). The findings about the structural validity of the scale is provided by factor analysis. As a result of Component Factor Analysis four dimensions as "sensibility to employees", "trust to administrator", "openness to modernity", and "communication climate" are revealed. The total reliability coefficient of the study is 0.97 . The reliability coefficients for the four dimensions are calculated as 0.92 for sensibility to employees; 0.95 for trust to administrator; 0.75 for openness to modernity, and 0.92 for communication climate. As a result, it is found out that reliability coefficients for the internal validity of the subscales are high (Yılmaz, 2005). In order to determine the appropriateness of the scale for factor analysis, KMO (Kaiser- Mayer- Olkin) and Barlett tests are repeated. KMO value of 0.938 is found out and Barlett Test is $\mathrm{p}=.000(\mathrm{p}<.01)$. So, it is concluded that the data is distributed normally. Reliability coefficients for the sub-dimensions are found out as 0.92 for sensibility to employees; 0.93 for trust to administrator; 0.85 for openness to modernity, and 0.97 for communication climate, while overall 
reliability coefficient of the scale is calculated as 0.96 .

"Organizational Silence Scale" developed by Dyne, Ang \& Botero (2003), and adapted to Turkish by Erdoğan (2011) is the second data gathering tool of the study. The original scale developed by Dyne, Ang \& Botero (2003) consists of 27 questions and 6 sub-dimensions. Three of these sub-dimensions are about organizational voice, while three of them are about organizational silence. Since the study search for the opinions of the teachers and administrators about organizational silence, the study deals with the three types of silence, that are "acquiescent silence", "defensive silence" and "prosocial silence". Remaining three dimensions about organizational voice are dismissed. Similar practices can be seen in present studies too (Eroğlu, Adıgüzel \& Öztürk, 2011; Kolay, 2012; Yüksel, 2014). Cronbach’s Alpha value for the organizational silence scale's acquiescent silence dimension is calculated as 0.76 , while the same value is 0.87 for defensive silence and 0.81 for prosocial silence (Erdoğan, 2011). Factor analysis and reliability analysis for the scale are repeated. In order to determine the appropriateness of the scale for factor analysis, KMO (Kaiser- Mayer- Olkin) and Barlett tests are repeated, yielding a KMO value of 0.805, which shows the sampling is big enough. Barlett Test results as $\mathrm{p}=.000$ ( $\mathrm{p}<.01)$, therefore it is concluded that the data is distributed normally. Repeating reliability tests for the scale, Cronbach's Alpha values are found out as 0.77 for acquiescent silence; 0.83 for defensive silence; and 0.87 for prosocial silence, while the overall Alpha value for the scale is calculated as 0.89 .

\subsection{Data Analysis}

The data is analyzed using SPSS 17.0. The descriptive statistical values such as mean values and standard deviations for both dimensions and overall are calculated for the participants opinions on organizational trust and organizational silence. For the relationship between trust and silence correlation and regression analysis are done in order to reveal how much perceived trust predicts silence.

\section{Findings}

In this section, the results of the analysis are given and explained in the form of tables. Table 1 shows the opinions of the participants about organizational silence and organizational trust.

Table 1. Arithmetic mean values and standard deviations of organizational silence and organizational trust.

\begin{tabular}{llll}
\hline Organizational Silence & & $\bar{X}$ & $\mathrm{~S}$ \\
\hline & $\mathrm{N}$ & 3,0375 &, 99772 \\
\hline Acquiescent Silence & 160 & 2,3953 &, 91178 \\
Defensive Silence & 160 & 3,5800 & 1,00419 \\
ProSocial silence & 160 & 2,8755 &, 57234 \\
Total & 160 & $\bar{X}$ & $\mathrm{~S}$ \\
Organizational Trust & $\mathrm{N}$ & 3,8250 & 1,23027 \\
& 160 & 4,5687 & 1,09994 \\
Sensibility to employees & 160 & 3,7361 & 1,06339 \\
Trust to Administrator & 160 & 4,4112 & 1,03726 \\
Openness to modernity & 160 & 3,9681 &, 88375 \\
Communication climate & 160 & & \\
Total & & \\
\hline
\end{tabular}

When looked at the opinions of the participating teachers related to organizational silence reveals that they "seldom" show acquiescent silence, ( $\bar{X}=3,0375)$, "sometimes" show defensive silence, $(\bar{X}=2,3953)$ and "frequently" show prosocial silence $(\bar{X}=3,5800)$, while they "seldom" show silence in overall $(\bar{X}=2,8755)$. When the results of analysis related to the organizational trust is examined, it can be seen that perceptions of teachers are at "usually" level for sensibility to employees ( $\bar{X}=3,8250$ ) and openness to modernity ( $\bar{X}=3,7361)$ dimensions, at "always" level for trust to administrator $(\bar{X}=4,5687)$ and communication climate $(\bar{X}=4,4112)$ dimensions. Overall organizational trust of the teachers is at "usually" level $(\bar{X}=3,9681)$. These findings reveal that the teachers working at vocational high schools have high perceived organizational trust and have a mid-level tendency towards organizational silence, while they frequently keep silent for "prosocial silence" (Table 1).

Table 2 shows the analyses about the relationship between organizational silence and organizational trust. 
Table 2. Correlation table of the relationship between organizational silence and organizational trust.

\begin{tabular}{|c|c|c|c|c|c|c|}
\hline & & $\begin{array}{l}\text { Sensibility to } \\
\text { employees }\end{array}$ & $\begin{array}{l}\text { Trust to } \\
\text { administrator }\end{array}$ & $\begin{array}{l}\text { Openness to } \\
\text { modernity }\end{array}$ & $\begin{array}{l}\text { Communication } \\
\text { climate }\end{array}$ & $\begin{array}{l}\text { Total } \\
\text { organizational } \\
\text { trust }\end{array}$ \\
\hline \multirow{2}{*}{$\begin{array}{l}\text { Acquiescent } \\
\text { silence }\end{array}$} & $\mathrm{R}$ & -.011 & -.107 & .013 & -.001 & -.019 \\
\hline & $\mathrm{p}$ & .882 & .180 & .870 & .986 & .810 \\
\hline \multirow{2}{*}{ Defensive silence } & $\mathrm{R}$ &,- 018 &,- 108 & ,034 &,- 052 &,- 048 \\
\hline & $\mathrm{p}$ &, 821 &, 176 & ,665 &, 511 & ,547 \\
\hline \multirow[t]{2}{*}{ ProSocial silence } & $\mathrm{R}$ &, $244^{* * 2}$ &, $242^{* * 1}$ &, 135 &, $352^{* * 2}$ &, $334^{* * *}$ \\
\hline & $\mathrm{p}$ &, 002 &, 002 & ,088 &, 000 &, 000 \\
\hline Total & $\mathrm{R}$ &, $179^{*}$ &, 075 &, $184^{*}$ &, $249^{* * *}$ &, $232^{* * *}$ \\
\hline $\begin{array}{l}\text { organizational } \\
\text { silence }\end{array}$ & $\mathrm{p}$ &, 024 &, 345 &, 020 &, 002 & ,003 \\
\hline
\end{tabular}

* Correlation is bidirectional and significant at 0.05 level ** Correlation is bidirectional and significant at 0.01 level

When the correlation table is examined, it can be seen that there is no significant relationship between acquiescent silence and defensive silence sub-dimensions of organizational silence and sub-dimensions of organizational trust. However it can be stated that there is a two-way negative relationship among each sub dimension of organizational trust and acquiescent silence and defensive silence sub-dimensions of organizational silence, except openness to modernity. This means that when sensibility to employees, trust to administrator and perceived trust to the communication climate decrease, sub-dimensions of organizational silence, acquiescent silence and defensive silence increase (Table 2).

Moreover, there is a two-way positive relationship between prosocial silence and sensitivity against employees $(\mathrm{r}=.244$, $\mathrm{p}<.01$ ). Similarly, there are positive two-way significant relationships between prosocial silence and trust to administrator $(\mathrm{r}=.242, \mathrm{p}<.01)$, prosocial silence and communication climate $(\mathrm{r}=.352, \mathrm{p}<.01)$ prosocial silence and organizational trust overall $(\mathrm{r}=.334, \mathrm{p}<.01)$. When sensibility to employees, trust to administrator, communication climate and overall organizational trust increase, prosocial silence behavior decrease. In total, it can be seen that there is a positive two-way significant relationship between organizational silence and sensibility to workers $(r=.179, \mathrm{p}<.05)$, openness to modernity $(r=.184, p<.05)$, communication climate $(r=.249, p<.01)$ and between overall organizational silence and organizational trust $(\mathrm{r}=.232, \mathrm{p}<.01)$ (Table 2$)$.

Table 3. Multiple Linear Regression analysis about organizational trust predicting organizational silence

\begin{tabular}{|c|c|c|c|c|c|c|c|c|}
\hline $\begin{array}{l}\text { Independent Variable } \\
\text { Organizational Trust }\end{array}$ & B & $\begin{array}{l}\text { Standard } \\
\text { Error }\end{array}$ & $\beta$ & $\mathrm{T}$ & $\mathrm{P}$ & $\mathrm{F}$ & $\mathrm{R}$ & $\mathrm{R}^{2}$ \\
\hline Sensibility to employees &,- 180 & ,377 &,- 334 &,- 477 & & & & \\
\hline Trust to administrator &,- 209 & ,191 &,- 401 & $-1,090$ & & & & \\
\hline Openness to modernity &,- 081 & 144 &,- 174 &,- 562 & $0,02 *$ & 2,733 & 0,082 & 0,052 \\
\hline Communication climate &,- 312 &, 784 &,- 566 &,- 398 & & & & \\
\hline Organizational Trust & ,960 & 1,559 & 1,483 & ,616 & & & & \\
\hline
\end{tabular}

Dependent Variable: Organizational Silence *p<.05

According to the results of multiple linear regression analysis given at Table 3 , organizational silence is taken as dependent variable and organizational trust and its sub-dimensions are taken as independent variables. Sub-dimensions of organizational trust, "sensibility to employees", "trust to administrator", "openness to modernity" and "communication climate" predict teachers' organizational silence significantly $\left(\mathrm{R}=0,082, \mathrm{R}^{2}=0,052\right.$, $\left.\mathrm{p}<.05\right)$. It is seen that "sensibility to employees", "trust to administrator", "openness to modernity" and "communication climate" explain organizational silence at 5\% level. Standardized $\beta$ (Beta) effect shows that "communication climate" is the dimension which predicts organizational silence the most $(\beta=-.566, \mathrm{p}<.005)$, followed by "trust to administrator" $(\beta=-.401$, $\mathrm{p}<.005)$, "sensibility to employees" $(\beta=-.334, \mathrm{p}<.005)$ and "openness to modernity $(\beta=-.174, \mathrm{p}<.005)$, respectively. Statistically significant results are got at the end of the F test conducted for total variance explanation $(F=2,733$, Sig $=.002)$

\section{Discussion, Results and Suggestions}

The first sub problem of this study, aiming to reveal the relationship between perceived organizational trust and organizational silence of teachers of vocational high schools, is "What is the teachers' perception about sub-dimensions of organizational silence "acquiescent silence", "defensive silence", "prosocial silence" and organizational silence in general? The findings related to this sub problem show that the teachers are at "rarely" level in "acquiescent silence" sub-dimesion and in general, at "sometimes" level in "defensive silence" and at "generally" level in "prosocial silence" sub-dimensions. Bakoğlu, Bige ve Aykut (2010) also study organizational silence on academician and found out that they generally show silence. Alparslan's (2010) study concludes that negative manners and communication structure of higher administrators result in silence of faculty members. Bathmunk (2011) in a study related to the relationship 
between leadership styles and organizational commitment finds out that employees do not keep their silence where there are transformational leaders. There are other studies on administrative behaviors being an important factor resulting silence (Bayram, 2010; Çakıcı, 2008; Çiçek Sağlam \& Yüksel, 2015; Morrison \& Milliken, 2000).

The first sub problem of this study is "What is the teachers' perception about sub-dimensions of organizational trust "sensibility to employees", "trust to administrator", "openness to modernity", "communication climate" and organizational trust in general?". The findings related to this sub problem show that the teachers are at "usually" level in "sensibility to employees" and "openness to modernity" dimensions, and at "always" level for "trust to administrator" and "communication climate" dimensions. When teacher opinions on organizational trust in general is evaluated, it can be seen that they have trust perception at "usually" level. This is quite pleasing, since trust to school administration would increase productivity. In their studies, Ning \& Jin (2009) state that employees who trust to their administrators feel more secure and comfortable, it results in increased employee motivation. Ning, Jin \& Mingxuan (2007) reveal that administrators affect on employee trust at mid-level, and there is a positive significant relationship between organizational trust and performance. Contrary to the findings of this study, some studies in Turkey conclude that organizational trust is either at low or medium level (Çağlar, 2011; Çokluk Bökeoğlu \&Yılmaz, 2008; Memduhoğlu \& Zengin, 2011; Özer, Demirtaş, Üstüner \& Cömert, 2006; Yıldız, 2013; Yılmaz, 2009).

The third sub problem of the research is "Is there a significant relationship between teachers' silence behavior and perceived trust to the school administration?". According to the findings, there are two-way negative relationships among sub dimensions of organizational trust, "sensibility to employees", "trust to administrators" and "communication climate", and sub-dimensions of organizational silence "acquiescent silence" and "defensive silence". In other words, the decrease in sensibility to employees, trust to administrator and communication climate result in an increase in acquiescent silence and defensive silence. Moreover, there is a positive two-way relationship between prosocial silence and sensitivity against employees. Similarly, there are two-way, positive and significant relationships between prosocial silence and trust to the administrator and communication climate dimensions, and overall organizational trust. When there is an increase in teachers' perception of sensibility to employees, trust to administrator, communication climate and total organizational trust, it results in a decrease in prosocial silence. In general, there are two-way positive and significant relationships among organizational silence behavior and organizational trust's "sensibility to employee", "openness to modernity" and "communication climate" sub-dimesions and organizational trust in general. As a result it can be said that higher organizational trust of teachers result in less organizational silence. Binikos (2008) states that when employees feel organizational trust, they tend to talk about what goes on in the organization more freely, otherwise they tend to keep their silence. Vakola \& Bouradas (2005) find a significant relationship between organizational silence and organizational commitment in their research. Khalid \& Ahmed (2016) similarly discovere a positive relationship between employees' silence and organizational policies in their study. Karaca Cakinberk et al., (2014), in a study aiming to find out the relationship between faculty members' organizational trust and their organizational silence, find a statistically significant relationship in negative direction close to mid-level between employees' organizational trust perception and organizational silence behavior. Similarly, Fard \& Karimi (2015) also find a significant and reverse relationship between organizational trust and organizational silence. Dedahanov \& Rhee (2015) conclude that there is a relationship between organizational trust and acquiescent silence, and there is also a relationship between trust against supervision and defensive silence. They also find out that there is a strong relationship between acquiescent silence and organizational commitment.

Fourth sub problem of the study is "Does teachers' perceived trust to school administration significantly predict organizational silence?". According to the findings of the study, trust to sensitivity against employees, trust to the administrator, openness for innovation and communication dimensions predict teachers' organizational silence significantly. To make it clarify, perceived organizational trust of teachers affect organizational silence. Similarly to the results of this research, Karaca Cakinberk, Polat Dede \& Yilmaz (2014) also find out that organizational silence affect organizational trust. Fard \& Karimi (2015) conclude that organizational trust directly affects organizational silence, and organizational silence directly affects job satisfaction and organizational commitment. Organizational trust is very important for highly motivated and dedicated employees who have high job satisfaction. Kath, Magley \& Marmet (2010), conclude that for those employees with high job satisfaction and commitment, organizational trust is very important and administrators and supervisors need to be careful while dealing with them. Zheng, Ke, She\& Zheng (2008) state that organizational trust should be ensured in order to decrease organizational silence. In a study namely "Is Silence Killing Your Company?", Perlow \& Williams (2003) interview with various administrators and employees from different industries and find out that silence behavior results in overstress, hatred, embarrassment, low productivity and low job satisfaction.

In conclusion, organizational trust and organizational silence are interrelated subjects. As as result of a literature review, it can be seen that each subject is related to a different concept. Organizational trust and organizational silence are 
frequently studied with organizational justice, commitment, job satisfaction and performance. There are limited number of studies which emphasize on organizational trust and organizational silence together. Hopefully this study contribute to the literature to fill this gap. This study finds out that there is a two-way positive significant relationship between organizational trust and organizational silence. The research findings show that perceived organizational trust affects organizational silence behavior. High perceived organizational trust of teachers and low perceived organizational silence is a pleasing conclusion, and based on these findings, it can be said that creating a school culture and climate leading to higher perceived organizational trust and lower organizational silence seems to be important. Therefore it can be suggested that teachers and school administrators should be provided with necessary training to increase awareness of this subject. It can also be suggested to researchers to conduct further detailed -especially qualitative- studies in other parts of educational fields.

\section{References}

Alparslan, A. M. (2010). Örgütsel sessizlik iklimi ve iş gören sessizlik davranışları arasındaki etkileşim: Mehmet Akif Ersoy Üniversitesi ögretim elemanları üzerinde bir araştırma (Yayınlanmamış yüksek lisans tezi). Süleyman Demirel Üniversitesi Sosyal Bilimler Enstitüsü, Isparta.

Bakoğlu, R., Bige, A., \& Aykut, B. (2010). Remaining silent or not: Is power distance a barrier for academicians?. International Conference Human, Work, Organization-Humanization of Work and Modern Tendencies in Management, Poland.

Bathmunk, M. (2011). Liderlik tarzları ve örgütsel bağlllık ve örgütsel sessizlik arasındaki ilişki ve bir araştırma (Yayınlanmamış yüksek lisans tezi). Marmara Üniversitesi Sosyal Bilimler Enstitüsü, İstanbul.

Bayram, T. Y. (2010). Üniversitelerde örgütsel sessizlik (Yayınlanmamış yüksek lisans tezi). Abant İzzet Baysal Üniversitesi Sosyal Bilimler Enstitüsü, Bolu.

Binikos, E. (2008). Sounds of silence: Organisational trust and decisions to blow the whistle. SA Journal of Industrial Psychology, 34(3), 48-59. http://dx.doi.org/10.4102/sajip.v34i3.728

Bowen, F., \& Blackmon, F. (2003). Spirals of silence: The dynamic effects of diversity on organizational voice. Journal of Management Studies, 40(6), 1393-1417. http://dx.doi.org/10.1111/1467-6486.00385

Çağlar, Ç. (2011). Okullardaki örgütsel güven düzeyi ile öğretmenlerin mesleki tükenmişlik düzeyinin bazı değişkenler açısından incelenmesi. Kuram ve Uygulamada Eğitim Bilimleri -Educational Sciences: Theory \& Practice, 11(4), $1827-1847$.

Çakıc1, A. (2007). Örgütlerde sessizlik: Sessizligin teorik temelleri ve dinamikleri. Çukurova Üniversitesi Sosyal Bilimler Enstitüsü Dergisi, 16(1), 145-162.

Çakıcı, A. (2008). Örgütlerde sessiz kalınan konular, sessizliğin nedenleri ve algılanan sonuçları üzerine bir araştırma. Çukurova Üniversitesi Sosyal Bilimler Enstitüsü Dergisi, 17(1), 117-134.

Çakıı, A. (2010). Örgütlerde işgören sessizliği. Neden sessiz kalmayı tercih ediyoruz?. Ankara: Detay Yayıncılık.

Çiçek, S. A., \& Yüksel, A. (2015). The views of managers and teachers working in high schools about organizational silence. Turkish Studies, 10(7), 317-333. http://dx.doi.org/10.7827/TurkishStudies.8089

Çokluk, B. Ö., \& Yılmaz, K. (2008). İlköğretim okullarında örgütsel güven hakkında öğretmen görüşleri. Educational Administration: Theory and Practice. Spring, 54, 211-233.

Dedahanov, A. T., \& Rhee, J. (2015). Examining the relationships among trust, silence and organizational commitment. Management Decision, 53(8), 1843-1857. http://dx.doi.org/10.1108/MD-02-2015-0041

Dyne, L. V., Ang, S., \& Botero, I. C. (2003). Conceptualizing employee silence and employee voice as multidimensional constructs. Journal of Management Studies, 40(6), 1359-1392. http://dx.doi.org/10.1111/1467-6486.00384

Erdoğan, E. (2011). Etkili liderlik örgütsel sessizlik ve performans iliş̧kisi (Yayınlanmamış yüksek lisans tezi). Gebze İleri Teknoloji Enstitüsü, Sosyal Bilimler Enstitüsü, Gebze.

Eroğlu, A. H., Adıgüzel, O., \& Öztürk, U. C. (2011). Sessizlik girdabı ve bağl1lık ikilemi: İşgören sessizliği ile örgütsel bağll1lk ilişkisi ve bir araştırma. Süleyman Demirel Üniversitesi, İktisadi ve İdari Bilimler Fakültesi Dergisi, 16(2), 97-124.

Fard, P. G., \& Karimi, F. (2015). The relationship between organizational trust and organizational slience with job satisfaction and organizational commitment of the employees of university. International Education Studies, 8(11), 219-227. http://dx.doi.org/10.5539/ies.v8n11p219

Kahveci, G. (2010). İlköğretim okullarında örgütsel sessizlik ile örgütsel bağlllık arasındaki ilişkiler (Yayınlanmamış yüksek lisans tezi). Fırat Üniversitesi Sosyal Bilimler Enstitüsü, Elazı̆g. 
Karaca, C. A., Polat, D. N., \& Y1lmaz, G. (2014). Relationship between organizational trust and organizational sılence: An example of public university. Journal of Economics, Finance \& Accounting-JEFA, 1(2), 91-105.

Karasar, N. (2006). Bilimsel araştırma yöntemleri. Ankara: Nobel Yayın Dağıtım.

Kath, L. M., Magley, V. J., \& Marmet, M. (2010). The role of organizational trust in safety climate's influence on organizational outcomes. Accident Analysis and Prevention, 42, 1488-1497. http://dx.doi.org/10.1016/j.aap.2009.11.010

Khalid, J., \& Ahmed, J. (2016). Perceived organizational politics and employee silence: supervisor trust as a moderator. Journal of the Asia Pacific Economy, 21(2), 174-195. http:// doi/full/10.1080/13547860.2015.1092279

Kolay, A. (2012). Endüstri meslek liselerinde görev yapan ögretmenlerin örgütsel sessizlik ve örgütsel bağllllklarl arasındaki ilişki (Yayınlanmamış yüksek lisans tezi). Yeditepe Üniversitesi Sosyal Bilimler Enstitüsü, İstanbul.

Memduhoğlu, H. B., \& Zengin, M. (2011). İlköğretim okullarında örgütsel güvene ilişkin öğretmen görüşleri. $Y Y \ddot{U}$ Eğitim Fakültesi Dergisi, 8(1), 211-217.

Milliken, F. J., Morrison, E. W., \& Hewlin, P. F. (2003). An exploratory study of employee silence: Issues that employees don't communicate upward and why. Journal of Management Studies, 40(6), 0022-2380. http://dx.doi.org/10.1111/1467-6486.00387

Morrison, E. W., \& Milliken, F. J. (2000). Organizational silence: A barrier to change and development in a pluralistic world. Academy of Management Review, 25, 706-725.

Nakane, I. (2006). Silence and politeness in intercultural communication in university seminars. Journal of Pragmatics, 38(11), 1811-1835. http://dx.doi.org/10.1016/j.pragma.2006.01.005

Ning, L., \& Jin, Y. (2009). The effects of trust climate on individual performance. Higher Education Press and Springer -Verlag, 3(1), 27-49. DOI 10.1007/s11782-009-0002-6

Ning, L., Jin, Y., \& Mingxuan, J. (2007). How does organizational trust benefit work performance?. Higher Education Press and Springer-Verlag, 1(4), 622-637. DOI 10.1007/s11782-007-0035-7

Özer, N., Demirtaş, H., Üstüner, M., \& Cömert, M. (2006). Ortaöğretim öğretmenlerinin örgütsel güven algıları, (Secondary school teachers' perceptions regarding organizational trust). Ege Eğitim Dergisi, 7(1), 103-124.

Perlow, L., \& Williams, S. (2003). Is silence killing your company?. Harvward Business Review, 12, 3-8. http://dx.doi.org/10.1109/emr.2003.24935

Pinder, C. C., \& Harlos, K. P. (2001). Employee silence: Quiescence and acquiescence as response to perceived injustice. Research in Personnel and Human Resources Management, 20, 331-369. http://dx.doi.org/10.1016/s0742-7301(01)20007-3

Scott, R. L. (1993). Dialectical tensions of speaking and silence. Quarterly Journal of Speech, 79(1), 1-18. http://dx.doi.org/10.1080/00335639309384016

Vakola, M., \& Bouradas, D. (2005). Antecedents and consequences of organizational silence: An empirical investigation. Employee Relations, 27, 441-458. http://dx.doi.org/10.1108/01425450510611997

Yanık, C. (2012). Örgütsel sessizlik ile güven arasındaki iliski ve eğitim örgütlerinde bir arastırma (Yayınlanmamış yüksek lisans tezi). Yeditepe Üniversitesi Sosyal Bilimler Enstitüsü, İstanbul.

Yıldız, K. (2013). Öğretmenlerin örgütsel adalet ve örgütsel güven algıları. Abant İzzet Baysal Üniversitesi Sosyal Bilimler Enstitüsü Dergisi, 13(1), 289-316. http://dx.doi.org/10.11616/AbantSbe.315

Yılmaz, E. (2005). Okullarda örgütsel güven ölçeğinin geçerlilik ve güvenirlik çalışması. Selçuk Üniversitesi Sosyal Bilimler Enstitüsü Dergisi, 14, 567-580.

Yılmaz, K. (2009). Özel dershane öğretmenlerinin örgütsel güven düzeyleri ile örgütsel vatandaşlık davranışları arasındaki ilişki. Educational Administration: Theory and Practice, 15(59), 471-490.

Yüksel, A. (2014). Liselerde görev yapan ögrretmen ve yöneticilerin örgütsel sessizliğe ilişkin görüşleri (Yayınlanmamış yüksek lisans tezi). Uşak Üniversitesi Sosyal Bilimler Enstitüsü, Uşak.

Zheng, X., Ke, J., Shi, J., \& Zheng, X. (2008). Measurement of the silence of the employees in Chinese background and the impact of trust on it. Psychological Science, 40(2), 219-227.

\section{$(\infty)$ EY}

This work is licensed under a Creative Commons Attribution 3.0 License. 